\title{
RELASI PSIKOLOGIS DOKTER-PASIEN DALAM LAYANAN KESEHATAN : PERSEPSI, KOMUNIKASI, EMPATI DAN UNSUR KEPERCAYAAN
}

\author{
Moordiningsih \\ Universitas Muhammadiyah Surakarta
}

\begin{abstract}
Psychological relation between palient and his/her doctor could help the palient's healing process. This article is part of research about doctor's decision making which thy to comprehend doctor.patient psychological relationship. This qualitafive research inv olved 11 specialist doctors in Surakarta as informan. This research found that psychological aspects of doctor-patient relationship consist of physical attraction, cognilive schemas, stereofype and doctor's memory. Another doctor's psychological aspects that have their role on doctor-patient relation are communicationn shill, inteligence capacity, empathy, ability to bul'd palient irust and positive values.
\end{abstract}

Koywords; patient and doctorrolation

\section{Pengantar}

Dokter adalah orang penting (the significant person) bagi individu-individu yang mengharapkan kesembuhan atas penyakitnya dan juga bagi mereka yang berupaya memelihara kesehatannya. Arti penting dokter menjadi semakin terasa saat individu-individu berada dalam ancaman kesehatan yang kongkrit. Pada saat sekarang begitu banyak isu penyakit yang menjadikan individu berada dalam ancaman kesehatan, seperti flu burung, demam berdarah, HIV/AIDS dan sebagainya. Untuk mendapatkan rasa aman dari ancamanancaman penyakit tersebut, arti penting dokter menjadi semakin nyata bagi orangorang yang sakit maupun terancam penyakit.

Delem memberikan layanan terhedap pasien, dokter melakukan hubungan secara fungsional dan emoslonal. Hubungan dokter dan pasien tidak hanya terbetas delam proses pengobatan dan penyembuhan penyakit serta pemeliharaan kondlsi paslen, namun juga terdapat Interaksl ps|kologis yang turut mendukung keberhasilan suatu layanan kesehatan.
Aspek fungslonal yang peling pokok dalam Interaksi entera dosen dan pasien adalah adanya kompetensi yang dimiliki dosen saat menanganl penyakit paslen atau saat melakukan pemeliharaan kesehatan. Demikian halnya dengan aspek emosional. Dinamika profesi dokter dalam memberikan pelayanan kesehaten bagi pasien menarik untuk dleksplorasi secare mendelam, kerene di dalam proses penengenen pesien in terkandung muaten-muatan psikologis yang tak terlepaskan deri sisi manusiawi seorang dokter.

Relesi antara dokter dan pasien menarik untuk dikeji melalui telaah psikologis karena dl dalam hubungan tersebut tidak hanya sekedar suatu hubungan pengobatan suetu penyekit, melainkan juga hubungan psikologis entara dokter dan pasien. Beberapa contoh kesus memberikan gambaran bahwa suatu penyakit yang sama ditangani oleh dokter yang berbeda dapat menghasilkan kemajuan penyembuhan yeng berbeda. Contoh yang lein edelah pasien yang hanya mau ditengani oleh dokter tertentu di rumah sakit, walaupun terdapat dokter yang memiliki keahlian yang sama 
bahkan lebih. Contoh di atas menunjukkan adanya peran kepercayaan pasien terhadap dokter.

Tulisan dengan tínjauan psikologis inl diharapkan dapat memberikan deskripsi untuk memahami relasi psikologis yang terjadi antara dokter dan pasien dalam proses pelayanan kesehatan. Melalui penelitian ini ingin diketahui tema-tema apa saja yang muncul dalam relasi antara dokter dank lien.

\section{Pertanyaan Penelitan}

Tema-tema apa saja yang muncul dalam relasi psikologi dokter pasien?

\section{Metode}

Tulisan ini menyajikan bagian dari sebuah penelitian tentang proses pengambilan keputusan dokter, khususnya dalam proses menegakkan diagnosa bagi pasien. Penelitlan dilakukan dengan pendekatan kualitatif tehadap 11 orang dokter spesialis di sebuah rumah sakit kotamadya Surakarta selama kurang lebih 1 bulan pada pertengahan tahun 2005. Metode penelitian yang digunakan adalah wawancara mendalam semi terstruktur dan observasi kepada para informan penelitian, dalam hal ini dokter-dokter spesialis dari berbagai bangsal yang ada di rumah sakit, seperti bangsal penyakit dalam, paru, telinga, mata, jantung, maupun bangsal kebidanan dan kandungan. Analisis data dilakukan dengan metode analisis isi (Flick, 2002) dengan melakukan displai data dalam bentuk matriks, reduksi data ke dalam tematema penting wawancara yang berkaitan dengan relasi dokter-pasien dan interpretasi data untuk mengkaji teori-teori psikologi.

\section{Hasit Penelitian dan Pembahasan}

Setelah dilakukan wawancara dan observasi terhadap sebelas responden, diperoleh tema-tema penelitian sebagai berikut: (1) Kemampuan dokter selama proses pemeriksaan, (2) Persepsi dari dokter ke pasien, (3) Kemampuan komunikasi dokter dan pasien, (4) Kemampuan dokter untuk berempati dan memahami karakter pasien, (5) Kepercayaan (trust) dari pasien ke dokter.

\section{Pemeriksaan dokter kepada pasien}

Ketika individu merasakan adanya kelainan dalam tubuhnya seperti gejala panas, luka, nyeri, sakit di organ tubuh tertentu maupun gejala-gejala yang lain, maka individu berupaya untuk menyembuhkan rasa sakit itu. Salah satu usaha yang dilakukan adalah pergi ke dokter untuk menjalani pemeriksaan dan mendapatkan pengobatan.

Pasien akan mengutarakan gejalagejala yang dirasakan kepada cookter, keluhan awal pasien kepada dokter ini dalam prosedur kedokteran sering ditempatkan sebagai keluhan utama pasien (chief complain).

-...jadi penderita datang ke dokter itu adalah [dengan] keluhan pertama yang keluardari pasien itu... oleh dokter atau df bidang medls, itu disebut keluhan utama..." $(F)$

"... Ketika orang datang blasanya ada keluhan utama (chief complain) keluhan utama ini dipakai dasar untuk mengembangkan inirdiagnosa] ..." $(H)$

Selama proses pemeriksaan awal berlangsung terdapat aspek-aspek psikologis yang menyertai proses ini seperti persepsi dokter, komunikasi dokter dan pasien, slkap empati dokter dan kepercayaan pasien kepada dokter. Aspekaspek psikologis tersebut lebih lanjut diuraikan sebagai berikut:

\section{Persepsi dokter kepada pasien}

Persepsi adalah sebuah proses penilaian secara subyektif yang dilakukan oleh dokter ketika bertemu dengan pasien. Penilaian yang terjadi sering berkaitan dengan jenis kelamin, status sosial ekonomi pasien, latar belakang keluarga, latar belakang pendidikan dan pekerjaan pasien serta pengetahuan pasien tentang riwayat 
penyakit yang dirasakan. Beberapa kutipan hasil wawancara berikut kiranya memberi gambaran yang cukup lengkap:

«... yang bersangkutan sendiri \{pasien\}... kadang-kadang dari pendidikannya yang berbeda, juga sudah berbeda pula... misainya... untuk ngomong bahwa ini ampek atau rasa sakit dada...dengan rasa sesak nafas .. Jalu tempatnya d mana ... atau pun lokasinya di mana, misal penjalarannya ke mana, ....jadf kalau orang [pasien] tidak tahu itu pun, kadangkadang kita [dokter] memberikan suatu hasil yang berbeda..." (A)

"... misalnya katakanlah...seorang wanita pekerja seks yang...datang, karena itu pekerja seks keluhannya keputihan ya .. jangan lang sung kita pikir karena subyektif... oh ini mesti penyakit kelamin...jangan langsung begitu...mungkin [ada] kemungkinankemungkinan lain... harusnya tetap obyektif sesuai dengan standar protap ..."(C)

Pembentukan kesan dapat terjadi sebagai suatu proses mempertalikan suatu sifat atau karakter kepada orang lain. Kesankesan ini bisa dibentuk pada saat awal pertemuan interaksi interpersonal, namun juga bisa meningkat seiama proses interaksi sosial. Pada proses ini, bukan hanya kesan yang dibentuk dan dimodifikasi namun juga identitas-identitas yang dipengaruhi situasi, berisi peran-peran sosial dimunculkan dan dinegosiasikan (Stephan \& Stephan, 1985).

Ketika individu berinteraksi dengan orang lain, maka sering terjadi proses persepsi personal yaitu proses pembentukan kesan terhadap orang lain. Kesan tersebut sering tidak akurat karena sering terjadi bias maupun kekeiiruan-Kekelíruan selama proses pembentukan persepsi.

"You shouldn't judge a book by it's cover". Menilai orang lain hanya dari siși luarnya saja seringkali menghasilkan kesimpulan yang kurang tepat, namun hal ini sering ditemui dalam masyarakat. Penilaian terhadap kepribadian orang lain sering digerakkan oleh penampilan luar, khususnya daya tarik fisik. Individu cenderung menilai kepribadian yang positif dari individu lain yang dilihat menarik dari penampilan, dinilaí lebih peka, menyenangkan, ramah, menarik dan disukai daripada yang individu yang tidak menarik (Dion, 1986; Patzer, 1985 dalam Weiten, 1992).

Selain karena daya tarik fisik, faktor lain yang mempengaruhi persepsi personal adalah penggunaan skema kognitif, stereotipe, distorsi ingatan (Weiten, 1992). Skema adalah struktur kognitif yang memandu individu dalam memproses informasi. Setiap orang memiliki skema terhadap sesuatu dari objek yang tidak bergerak seperti meja, rumah maupun skema tentang aktivitas manusia. Individu menggunakan skema untuk mengorganisasikan iingkungan di sekitarnya termasuk lingkungan sosial. Skema sosial adalah kelompok-kelompok gagasan yang terorganisasi tentang kategori-kategori peristiwa sosial maupun manusia. Stereotipe adalah keyakinan-keyakinan yang dimiiki oleh individu bahwa orang lain memiliki karakteristik tertentu karena keanggotaannya dalam suatu kelompok sosial. Sterotipe dan skema kognitif dapat menyebabkan bias-bias daiam persepsi terhadap orang iain, serta dapat menunjukkan penegasan terhadap harapan individu terhadap orang iain, demikian pula ingatan individu terhadap suatu hai maupun peristiwa.

Keempat hal tersebut yaitu ketertarikan fisik, skema kognitif, stereotipe maupun faktor ingatan juga dapat mempengaruhi dokter ketika melakukan pemeriksaan awal kepada pasien. Hal ini berpengaruh dalam proses pengumpulan informasi awal sebelum dokter menegakkan diagnosa, dan mungkin terjadi bias-bias subjektif dalam proses pemeriksaan pasien. Pemrosesan informasi dokter secara kognitif dapat mempengaruhi proses pembentukan kesan terhadap pasien secara subjektif, sehingga dokter diharapkan dapat tetap bersikap objektif mengacu pada standar prosedur pemeriksaan yang telah disepakati. 
Komunikasi dokter dan pasien

Kemampuan komunikasl dokter dalam menggali informasi gejala-gejala yang diderita pasien berperan besar dalam proses pemeriksaan awal pasien. Seperti penjelasan dari informan penelitian:

"...Anamnesis itu kalau tepa belul dan yang menjawab jujur...maka itu sumbangannya besar sekali...bisa dikatakan kita bisa menegakkan [diagnasa] $75 \%$ dengan anamnesis saja..." (H)

Komunikasi dalam proses anamnesa tidak hanya dilakukan pada pasien (auto anamnesa), namun juga pada orang lain yang mengetahui riwayat penyakit pasien (allo anamnesa). Sumbangan yang cukup besar dari proses komunikasi dalam anamnesis dokter kepada pasien menunjukkan bahwa kemampuan berkomunikasi menjadi syarat mutlak bagi seorang dokter untuk mendapatkan informasi yang lengkaptentang gejala-gejala yang dialami pasien. Apabila seorang dokter tidak mampu melakukan proses komunikasi maka ketidakmampuan ini dapat berakibat pada ketidaktepatan diagnosis yang ditegakkan karena informasi tidak dapat tergali dari pasien. Sebagaimana kutipan wawancara berikut ini:

"...makanya kita [dokter] harus membesarkan hati pasien, kila lidak [berbohong] tetapl membesarkan hati, dan kita beritahu keluarganya bahwa penyakit ini. memang penyakit yang berbahaya...jadi keluarganya harus tahu...kalau keluargenya tidak tohu, penyakitnya diobati dokter kok tidak sembuh-sembuh malah monjadijadi... jadi kan kita harus hati-hati dalam memberi tahu pasien.( C)

Komunikasi pasien dan dokter menjadi penting karena merupakan awal pengobatan. Komunikasi terjadl karena suatu tujuan. Tujuan pasien lalah memberikan keterangan tentang penyakit, supaya dokter mengetahui jenis penyakit dan bagaimana melakukan pengobatan. Tujuan dokter adalah menerangkan rencana pengobatannya untuk mendapatkan persetujuan dari pasien. Komunikasi akan sla-sia bila tidak mencapai tujuan. Komunikasi yang sia-sia hi disebut sebagai miskomunikasi antara dokter dan pasien. Miskomunikasi terlihat bila dokter tidak melakukan apa yang diharapkan pasien. Pasien menginginkan agar dokter melakukan upaya pengobatan dengan sebaik mungkin. Oieh karena itu, dapat dlkatakan bahwa miskomunikasi adaiah awal sengketa antara paslen dan dokter (Azwar, 2002).

Pendekatan psikologi sosial menjelaskan bahwa bila individu-individu berinteraksi dan saling mempengaruhi, maka terjadilah proses belajar yang meliputi aspek kognitif dan afektif, proses penerimaan lambang-lambang (Komunikasi) dan mekanisme penyesuaian diri seperti sosialisasi, melakukan peran sosiai, identifikasi, proyeksi dan sebagainya.

Pertukaran informasi antara dokter dan pasien dalam proses pemeriksaan awal akan menunjang proses pemeriksaan lanjutan apabila dokter memiliki kemampuan menggall informasi dari pasien serta fihak pasien maupun keluarga memberikan informasi yang jelas tentang keluhan penyakit yang dirasakan.

\section{Sikap empati dokter kepada pasien}

Sikap seorang dokter untuk bisa merasakan apa yang sedang dialami oleh pasien turut berperan dalam proses penegakan diagnosa maupun dalam pemberian tindakan yang hendak diberikan dokter. Sebagaimana yang dikemukakan salah seorang informan:

"...kita sebagai dokter ... hans empati dulu ya...itu penting... maksudnya tahu perasaan pasien ... seandainya saya jadi pasien ... nha ...ltu ...tanpa begitu ... ya mungkin...ngawur ldalam proses pemeriksaan I..." (G) 
Empati adalah suatu bentuk ketrampilan, sehingga empati adalah suatu hal yang bisa dipelajari. Empati memegang peran penting dalam proses perawatan (Mayeroff dalam Egan, 1990). Hal ini seperti kutipan penuturan seorang dokter dalam memahami pasien sebagai berikut:

*...eha Ini, pasion yang datang ke kita [dokter] ith kan jelas orang sakit, satu .. jelas orang sakit, sakit apapun itu mudah tersinggung... lya kan? Coba and a... mudah tersinggung ... terus yang kedua, membayar ya...pasien datang ke dokfer itu kan membayar, sudah sakit, masih mbayar, kok doktere galak ... ya, wajar tho kalau pasiennya itu sakit, tapi dokternya menanggapi dengan baik, mendengarkan semua keluhan...iva tho? Memberikian solusi, memberikan konsultasi...pasti sakitnya akan berubah, sehingga dengan...tanggapan yang demikian, mengeluarkan uang pun dengan sangat sukarela..." $(F)$

Dokter yang mampu berempati atas keluhan yang dirasakan pasien cukup membantu dalam proses pemeriksaan pasien. Hal ini dapat terjadi karena dokter seolah-olah mampu merasakan bagian organ tubuh yang sakit sehingga ketika melakukan proses pemeriksaan dapat mendeteksi arah perjalanan penyakit sesual pengetahuan yang dimiliki. Dokter juga akan bisa melihat dari sisi pasien, sesuatu yang hendak diperjuangkan untuk bertahan hidup, dan yang diinginkan pasien untuk sembuh. Hal ini mensyaratkan kemampuan dokter untuk dapat mengkomunikaslkan pemahaman atas penyakit kepada pasien.

\section{Kepercayaan paslen kepada dokter Kedatangan pasien kepada dokter} yang dilandasi atas dasar kepercayaan pasien tersebut kepada dokter sering disebut sebagal faktor yang cukup berpengaruh dalam proses penyembuhan pasien. Kepercayaan ini menimbulkan sugesti tidak langsung bagi paslen, bahwa pasien akan sembuh blla berobat kepada dokter yang dipercayainya. Seorang dokter menjelaskan fenomena ini dalam kutipan sebagai berikut:

-...kalau percaya itukan pasrah ada...kalau sudah pasrah ada itu hubungan antara kita dan supra naturai... kalau sudah terbina hubungan itu, itu sangat membantu dalam penyembuhan ..." (D)

-...Jadi sebetulnye, hubungan antara pasien dan dokfer in tidak mutlak hanya karena obat saja...tapi karena... kepercayaan [pasion-doktor] ..." (F)

Unsur kepercayaan dalam relasí interpersonal antara dokter dan pasien membantu dalam kelancaran proses penyembuhan pasien. Unsur kepercayaan dapat tumbuh dalam hubungan interpersonal sebagai suatu proses penggabungan dalam pengambilan resiko bersama, d mana kedua belah fihak mengijinkan mereka berdua untuk mendapatkan resiko, dengan berperilaku yang bertujuan untuk menempatkan keperiuan orang lain di atas kepentingan sendiri (Kelley dan Thibaut, dalam Manstead \& Hewstone, 1996). Pasien percaya bahwa dokter akan mendahulukan kepentingan pasien dibandingkan kepentingan dokter sendiri. Pasien percaya bahwa dokter tidak akan melakukan perbuatan yang dapat merugikan pasien.

Mishra (Faturochman, 2000) menjelaskan bahwa kepercayaan juga sering disamakan dengan kerjasama atau kooperasi. Kedua konsep ini jelas berbeda, namun dalam kehldupan sehari-hari aplikasinya sering bersamaan. Kerjasama yang baik pada umumnya dilandasi oleh kepercayaan yang tinggi. Melalui kerjasama, kepercayaan dapat dibangun, tetapi tanpa kepercayaan sama sekali kerjasama tidak akan bisadibangun.

Kepercayaan terhadap orang lain dapat dibangun melalui bebagai cara. Dengan cara apapun kepercayaan dibentuk, proses ini harus menyentuh empat dimensi pokok kepercayaan yaltu kompetensi, keterbukaan, kepedulian dan reliabilitas (Mishra dalam Faturochman, 2000), Orang 
pada umumnya mempercayai pihak lain karena kampetensi yang dimiliki. Pasien yang berobat ke dokter atau dukun menganggap bahwa dokter atau dukun itu memiliki kemampuan untuk menyembuhkan sakltnya mesklpun harus melalui media tertentu.

Membangun kepercayaan antara dokter dan pasien, bisa dilakukan antara lain dengan cara:

1. Dokter memiliki kompetensi-kompetensi khusus yang berupa keahlian dalam menangani penyakit tertentu, sehingga pasien akan datang dengan kepercayaan bahwa dokter dapat menangani penyakitnya.

2. Kerjasama yang baik senantiasa terjalin antara dokter dengan setiap pasien yang datang. Dokter bersikap empati dan pedull serta mampu berkomunlkas| dengan pasien, menggali informasi yang lengkap dari pasien sehingga dapat memenuhi harapan pasien, yaitu kesembuhan dari penyakit yang dialami serta menegakkan diagnosa dengan benar dan memberikan terapl pengobatan yang tepat. Pasien akan merasa puas dengan layanan kesehatan yang dlberikan dokter.

3. Pasien yang memperoleh kepuasan dalam pelayanan kesehatan dari seorang dokter akan berperan sebagal mediator bagi pasien lain. Pasien Ini akan memberikan informasi yang positif tentang dokter, sehingga otomatis terjadi proses pemasaran dari mulut ke mulut (word of mouth). Hai ini akan meningkatkan kredibllitas dan kepercayaan masyarakat kepada dokter.

\section{Simpulan}

Hubungan interpersonai antara dokter dan pasien sebagaimana layaknya hubungan interpersonal yang lain, diwarnai muatan-muatan psikologis yang mampu mempengaruhl proses pelayanan kesehatan seorang dokter kepada pasien. Berbagai unsur yang bisa muncul antara iain: (1) Kemampuan dokter selama proses pemeriksaan, (2) Persepsi dari dokter ke pasien. (3) Kemampuan komunikasi dokter dan pasien, (4) Kemampuan dokter untuk berempati dan memahami karakter pasien, (5) Kepercayaan (trust) dari pasien ke dokter.

Unsur-unsur tersebut cukup memberikan kontribusi dalam proses pemberian layanan kesehatan kepada pasien terutama dalam penentuan diagnosa awal (working diagnosis) menuju ke diagnosis pasti (definitive diagnosis) hingga pemberian tindakan penanganan pasien. Hal ini bermuara pad a kepuasan pasien atas jasa layanan kesehatan yang disediakan dokter maupun rumah sakit, sehingga nantinya akan jarang didengar lagi laporan tentang kasus malpraktek dan digantikan dengan laporan tentang kepuasan pasien atas layanan kesehatan dokter.

\section{Daftar Pustaka}

Azwar, B. 2002. Buku Pintar Pasien: Sang Dokter. Jakarta: Kesaint Blanc.

Cooke, S. \& Slack, N. 1991. Making Management Decision. London: Pearson Education Limited.

Crabtree, B.F \& Miller, W.L. 1992. Doing Qualitative Research. Newbury Park, California: SAGE Publicatlons.

Djojosugito, M.A. 2004. Portanggungjawaban Prolisj Kasus Malpraktek Dokter. Maka!ah. Simposium "Malpraktek ditinjau dari segl Hukum dan Kedokteran". Surakarta: Fakultas Kedokteran Universitas Sebelas Maret Surakarta

Egan, G. 1990. The Skilled Helper; $A$ Systematic Approach b Effodive Helping. California: Brooks/Cole Publishing Company

Faturochman. 2002. Psikologl Keadilan. Yogyakarta: Pustaka Pelajar

Flick, U. 2002. An Introduction to Qualitative Research. London: Sage Publication 
Hanafiah, M. J. 1999. Kode etik kedokteran Indonesia dalam Etika Kedokteran \& Hukum Kesehatan. Editor. Hanafiah, M.J,Amir, A edisi ketiga. Jakarta: EGC

Manstead, R S.A\& Hewstone, M. 1996. The Blackwell Encyclopedia of Social Psychology. Oxford: Blackwell Publishers

Moleong, L.J. 2001. Metodologi Penellian Kualitatif. Bandung: PT Remaja Rosdakarya.

Morse, J.M, Swanson, J.M \& Kuzel, A.J. 2001. The Nature of Qualitative Evidence. California: Sage Publications.

Mulyata. 2004. Resiko dan Malpraktek Kedokteran. Makalah. Simposium "Malpraktek ditinjau dari segi Hukum dan Kedokteran*. Surakarta: Fakultas Kedokteran Universitas Sebelas Maret Surakarta
Neuman, W. L. 2003. Social Research Methods: Quantitative and Qualitative Approaches. Boston: Pearson Education Inc.

Setiono. 2004. Malpraktek Modik dalam Perspektif Hukum. Makalah. Simposium "Malpraktek ditinjau dari segi Hukum dan Kedokteran". Surakarta: Fakultas Kedokteran Universitas Sebelas Maret Surakarta

Sox, J.R. 1990. Medical Decision Making. India: Asia Publisher

Stephan, C.W. \& Stephan, W.G. 1985. Two Social Psychologies: on integrative approach. Illinois: The Dorsey Press. 